УДК 316. 28: 37.0

DOI: $\underline{10.35619 / \mathrm{iiu} . v 2 \mathrm{i} 11.220}$

Забіяка Ірина

кандидат педагогічних наук, викладач кафедри української та іноземної лінгвістики Луцького національного технічного університету, м. Луцьк, Україна ORCID: 0000-0002-9535-5490 e-mail: irina.zabiiaka@ukr.net

Лобанова Світлана кандидат педагогічних наук, доцент кафедри іноземних мов гуманітарних спеціальностей

Східноєвропейського національного університету імені Лесі Українки, м. Луцьк, Україна

ORCID: 0000-0002-4432-3552 e-mail: svitlanalobanova000@gmail.com

\title{
МІЖКУЛЬТУРНА КОМУНІКАТИВНА КОМПЕТЕНТНІСТЬ МАЙБУТНІХ ФАХІВЦІВ ТЕХНІЧНОГО ТА ГУМАНІТАРНОГО ПРОФІЛЮ У КОНТЕКСТІ ГЛОБАЛІЗАЦІЇ ОСВІТНЬОГО ПРОСТОРУ
}

\begin{abstract}
Анотація. У статті висвітлено проблемні питання формування та розвитку міжкультурної комунікативної компетентності у майбутніх фахівців технічного та гуманітарного профілю у контексті глобалізації освітнього простору. На підставі узагальнення основних наукових понятійно-категоріальних ознак досліджуваного феномену, міжкультурна комунікативна компетентність майбутнього фахівця технічного та гуманітарного профілю тлумачиться як інтегративна, динамічна, здатна до саморозвитку професійно-особистісна якість, що забезпечує успіх у розв'язанні завдань міжкультурної комунікації, адаптації та самореалізації фахівців технічного та гуманітарного профілю в іншомовному суспільстві. Розглянуто поняття «міжкультурна комунікативна компетентність», означено іiі структуру та основні складові, що мають бути закладені в основу iї формування. Розкрито сутнісні характеристики структурних складових міжкультурної комунікативної компетентності та ії компоненти як інтегративної якості особистості майбутнього фахівця. Обгрунтовано особливості формування міжкультурної комунікативної компетентності у майбутніх фахівців у процесі вивчення іноземних мов та визначено педагогічні технології, що забезпечують ефективне іiі формування.
\end{abstract}

Ключові слова: міжкультурна комунікативна компетентність, міжкультурна комунікація, міжнародна комунікація, фахівці технічного та гуманітарного профілю, професійно-комунікативні компетентності.

Постановка проблеми. У сучасному глобалізованому світі відбуваються докорінні зміни в усіх галузях соціально-культурної взаємодії, підвищується академічна мобільність, відбувається культурна, освітня та економічна інтеграція. Отже, створюються умови

(C) Забіяка I., Лобанова С., 2020 
багатополярного світу, які детермінують необхідність підготовки конкурентоспроможної та соціально успішної особистості - полікультурної і полілінгвальної.

Стабільність і благополуччя світу в третьому тисячолітті залежатимуть від здатності молодого покоління проявляти терпимість, повагу до інших культурних і соціальних особливостей, від волі й бажання зрозуміти й співпрацювати один 3 одним, шукати й знаходити шляхи врегулювання соціокультурних конфліктів.

Спрямованість на інтернаціоналізацію сучасної вищої освіти в умовах глобалізаційних процесів неминуче призводить до посилення взаємодії мов і культур, що обумовлює необхідність розвитку в студентів здатності ефективно реалізувати себе в професійних контекстах на рівні міжкультурної комунікативної компетентності.

Розвиток сучасного суспільства в умовах глобалізації та динаміки міжкультурних контактів, адаптація Інтернет-простору до потреб користувачів і забезпечення ефективності комунікації в різних сферах діяльності людини висувають принципово нові вимоги до якості вищої освіти в Україні.

Віденський університет видав робочий документ «Стратегічне значення міжкультурної компетентності для керівників проєктів у XXI столітті», в якому також наголошено, що в умовах глобалізації проєктний менеджмент має як ніколи враховувати проблеми, що виникають внаслідок міжкультурної комунікації з представниками іноді кількох країн одночасно (Brünnemann, 2013).

Актуальність цієї проблеми знайшла своє відображення в таких нормативних актах сучасної освіти, як Законі України «Про вищу освіту» (2017), «Національній стратегії розвитку освіти в Україні на період до 2021 року» (2013), «Стратегії комунікації у сфері європейської інтеграції на 2018-2021 роки» (2017).

Аналіз останніх досліджень 3 проблеми. Дослідження проблеми міжкультурної комунікативної компетентності як багатоаспектного феномену грунтуються не лише на наукових розвідках лінгвістики та соціології, а й психології, педагогіки, культурології, тобто на міжпредметному діалозі, в межах якого і відбувається дослідження означеного феномену, що розглядається як адекватне взаєморозуміння учасників, які є представниками різних національних культур.

Міжкультурна комунікативна компетентність $є$ предметом дослідження як вітчизняних, так і зарубіжних учених (В. Антонов, М. Бахтін, Ф. Бацевич, В. Біблер, Дж. Джексон, О. Зеліковська, С. Кожушко, О. Левашов, У. Лідс-Гурвіц, Л. Махній, І. Піллер, В. Петрук, Р. Портер, О. Рембач, О. Садохін, Л. Самовар, С. Тінг-Туми, Дж. Трейджер, Е. Холл, Г. Хофстеде, І. Шапран, О. Шестель та ін.).

Актуальність полікультурної освіти обгрунтовано в наукових розвідках (М. Анбер, I. Козубовська, І. Лощонова та ін.), кроскультурної освіти (М. Беннетт, А. Солодка та ін.), міжкультурної освіти (Р. Ауернхаймера, С. Ніколаєва та ін.), мультикультурної освіти (Дж. Бенкс, М. Орб та ін.), діалогу культур (В. Біблер, М. Каган та ін.), національної самосвідомості, національної культури (Л. Кондрацька, Р. Льюїс, Г. Терещук та ін.), організації суб'єкт-суб'єктної взаємодії учасників освітнього процесу (Г. Мешко, Н. Слюсаренко, А. Степанюк та ін.).

Формування міжкультурної комунікативної компетентності в системі вищої освіти розкрито в працях Р. Гришкової (студентів нефілологічних спеціальностей), Г. Копил (майбутніх фахівців 3 міжнародної економіки), I. Плужник (студентів гуманітарного профілю), О. Фролова (студентів економічного профілю), Т. Колодько та С. Шехавцової (майбутніх учителів іноземних мов). 
Різні аспекти підготовки фахівців технічного профілю, зокрема інженерів-механіків, інженерів-судномеханіків, вивчали О. Джеджула, У. Ляшенко, Н. Черненко та ін.

Заслуговують на увагу праці лінгвістів і лінгводидактів, у центрі дослідження яких широкий спектр зазначеної проблеми: визначені закономірності мови міжкультурного спілкування (В. Кабакчі), обгрунтовані перспективи розвитку міжкультурної комунікації, принципи, методи навчання країнознавчим аспектам (С. Верещагін, В. Костомаров), схарактеризовані форми невербального і вербального спілкування представників різних культур (Дж. Фаст). Соцільно-філософські аспекти міжкультурної комунікації висвітлено в роботах П. Донця, В. Манакіна, І. Намєстнікової.

Аналіз останніх досліджень і публікацій свідчить про те, що як вітчизняні, так i зарубіжні дослідники в галузі соціології, культурології, психології, лінгвістики, філософії та освіти виявляють підвищений інтерес до різних аспектів міжкультурної комунікативної компетентності.

Досліджуваний феномен постає як важливий результат діяльності вищої освіти, базовий показник іï якості в контексті глобальних тенденцій інтеграції освітнього простору в сучасному світі.

Мета статті - виявити особливості феномену міжкультурної комунікативної компетентності на сучасному етапі підготовки майбутніх фахівців технічного та гуманітарного профілю та обгрунтувати нові підходи до зазначеного явища.

Виклад основного матеріалу дослідження. Проблема набуття широкої культурологічної освіченості, здатності до міжнародної комунікації, міжнародного діалогу $\epsilon$ напрочуд актуальною в контексті професійного становлення майбутніх фахівців технічного профілю. Оскільки необхідність професійного й особистісного становлення студента зумовлена, 3 одного боку, культурними, освітніми та економічними євроінтеграційними процесами, а 3 іншого - умовами та змістом конкретно-предметної технічної галузі, в якій має функціонувати майбутній фахівець.

Тому у Законі України «Про вищу освіту» одними зі стратегічних завдань є «академічна мобільність», «академічна свобода», «міжнародна інтеграція у Свропейській простір вищої освіти, за умови збереження і розвитку досягнень та прогресивних традицій національної вищої школи» (2014).

У контексті цього дослідження важливий поділ міжкультурної компетентності та міжкультурної комунікативної компетентності. У своєму дослідженні ми дотримуємося поділу, запропонованого М. Byram (Byram, 2004): у першому випадку люди можуть взаємодіяти своєю рідною мовою з представниками інших країн і культур, використовуючи свої знання з міжкультурної комунікації, навички спілкування та встановлення контактів; в разі міжкультурної комунікативної компетентності взаємодія відбувається між представниками різних країн і культур іноземною мовою.

Особистість, яка володіє міжкультурною комунікативною компетентністю, здатна виступати міжмовним і міжкультурним посередником. Саме тому при навчанні іноземної мови необхідно прагнути до формування міжкультурної комунікативної компетентності.

Розкриття сутнісних i структурних складових міжкультурної комунікативної компетентності було здійснено також на основі документу Ради Європи «Загальноєвропейські компетенції володіння іноземною мовою» (Common European Framework of Reference: Learning, Teaching, Assessment) (2003). Викладені в цій системі методологічні положення дозволили не тільки встановити інтегративний характер міжкультурної комунікативної компетентності, наявність і взаємозв'язок лінгвістичної i соціокультурної складових, її структуру, а й дати авторське тлумачення цього поняття. 
На основі узагальнення основних наукових понятійно-категоріальних ознак досліджуваного феномена, міжкультурну комунікативну компетентність майбутнього фахівця технічного та гуманітарного профілю розтлумачено як інтегративну, динамічну, здатну до саморозвитку, професійно-особистісну якість, що забезпечує успіх у розв'язанні завдань міжкультурної комунікації, адаптацію та самореалізацію фахівця технічного профілю в іншомовному суспільстві.

Розглядаючи поняття міжкультурної комунікативної компетентності як складне інтегральне явище вважаємо, що воно охоплює щонайменше три важливих компоненти, а саме:

- знання усталених правил, етично-моральних норм спілкування і форм поведінки власного соціуму;

- знання аналогічних норм, традицій та звичаїв інших національно-лінгвокультурних спільнот та толерантне ставлення до них;

- узгоджене використання цих знань у стосунках 3 представниками інших культур, знаходження «комунікативного консенсусу» у міжкультурній взаємодії.

3 огляду на вищезазначене тлумачення міжкультурної комунікативної компетентності як інтегральної, вважаємо, що в основу іiі формування мають бути закладені такі складові:

- розвиток здатності рефлексувати власну і «чужу» культуру, що з самого початку формує доброзичливе ставлення до проявів «чужої» культури;

- збагачення знань про відповідну культуру для глибшого розуміння відносин між власною національною і «чужою» культурами;

- здобуття знань про умови соціалізації та інкультурації у національній і «чужій» культурі, про соціокультурні форми взаємодії, прийнятих в обох культурах.

Основними цілями процесу оволодіння міжкультурною комунікативною компетентністю $є$ :

- управляти процесом взаємодії;

- адекватно інтерпретувати його;

- здобувати нові культурні знання з контексту конкретної міжкультурної взаємодії, тобто освоювати іншу культуру в результаті комунікативних процесів.

Досягнувши зазначених цілей, майбутні фахівці технічного та гуманітарного профілю повинні володіти такими здібностями міжкультурної комунікації:

- адекватно сприймати та інтерпретувати різні культурні цінності;

- уміти сприймати різні культурні явища і представників інших культур 3 позицій емпатії;

- вміти змінювати своє оціночне ставлення щодо «чужої» культури відповідно до розширення досвіду міжкультурного спілкування;

- змінювати самооцінку в результаті осягнення «чужої» культури;

- набувати нові знання про «чужу» культуру 3 метою глибшого пізнання своєї національної культури;

- уміти аналізувати та систематизувати факти культурного життя;

- уміти синтезувати та узагальнювати свій власний досвід у міжкультурному діалозі.

Процес навчання іноземних мов є моделлю міжкультурної комунікації. У процесі вивчення іноземних мов майбутні фахівці технічного та гуманітарного профілю знайомляться з світовою культурною спадщиною, з традиціями і особливостями «чужих» культур, культурою міжособистісних стосунків.

Педагогічний досвід підтвердив, що використання особистісно-орієнтованих та інформаційно-комунікаційних технологій навчання іноземних мов позитивно впливає на 
успішне оволодіння студентами вміннями та навичками міжособистісного, міжкультурного i професійного спілкування. Одним із пріоритетних методів формування навичок міжкультурної комунікації під час вивчення іноземної мови $є$ використання мовленнєвих ситуацій, ситуативних завдань, наближених до майбутньої професійної діяльності.

Навчання іноземної мови 3 використанням зазначених педагогічних технологій забезпечує майбутньому фахівцеві комплекс необхідних професійно-комунікативних компетентностей, які проявляються в оволодінні студентами таких умінь та навичок:

- уміння розробляти ефективну стратегію комунікативної рольової поведінки в ситуаціях міжособистісного, міжкультурного і професійного спілкування;

- уміння працювати в команді, чітко й обгрунтовано формулювати завдання перед колективом, навчати інших;

- уміння знаходити компроміс в конфліктних ситуаціях, знімати міжкультурні комунікативні бар'єри;

- уміння розрізняти мовні та культурні стереотипи, знати особливості вербальної і невербальної комунікації, проявляти толерантність до «чужої» культури;

- оволодіння основами ділової комунікації: спілкування по телефону, проведення виробничих нарад, ведення документації, складання звітів, особиста та ділова кореспонденція;

- уміння розробляти структуру майбутніх переговорів 3 урахуванням особливостей ведення переговорів в інших культурах;

- уміння готувати i проводити презентації (самопрезентації) 3 урахуванням особливостей цільової аудиторії (в тому числі культурних) ;

- знання іноземної мови як інструменту спілкування з іноземними партнерами;

- знання особливостей національного менталітету для успішної комунікації $з$ діловим партнером.

Використовуючи особистісно орієнтовані та інформаційно-комунікаційні технології при вивченні іноземних мов, моделюючи можливі ситуації міжкультурної комунікації, ми створюємо умови для розвитку в студентів умінь інтеркультурної комунікації, занурення студента в майбутню професійну діяльність.

Цей аспект дуже важливий для майбутньої професійної діяльності фахівців технічного профілю, оскільки в системі професійних вимог передбачено високий рівень володіння навичками міжкультурної комунікації, уміння формувати комунікативну стратегію та займати активну позицію учасника міжкультурного комунікативного процесу.

Нами розглянуті критерії та показники сформованості міжкультурної комунікативної компетентності майбутніх фахівців технічного та гуманітарного профілю у процесі навчання іноземної мови (табл. 1).

Вочевидь, формування міжкультурної комунікативної компетентності передбачає якісні зміни у ставленні студента до світоглядних домінант життя і процесу навчання в університеті на підставі становлення адекватної ціннісної картини світу, усвідомлення важливої ролі міжкультурного спілкування в освітній, а надалі й у професійній діяльності.

Глобалізація суспільства не має означати відмову від власних культурних цінностей на користь цінностей іншої культури. Завдання сучасного фахівця полягає в тому, щоб гідно представляти свою країну і власну національну культуру. 
Таблиця 1

Критерії та показники сформованості міжкультурної комунікативної компетенції студентів технічного та гуманітарного профілю в процесі навчання іноземної мови

\begin{tabular}{|c|c|}
\hline Kpumepiï & Показники \\
\hline Особистісні якості & $\begin{array}{l}\text { Емпатія, активність, самостійність, культура взаємодії, } \\
\text { толерантність, повага до інших культур }\end{array}$ \\
\hline $\begin{array}{l}\text { Усвідомлення } \\
\text { культура }\end{array}$ & $\begin{array}{l}\text { Усвідомлення відмінностей і подібностей між } \\
\text { культурами, сформованість соціокультурних знань, } \\
\text { сформованість навичок міжкультурного спілкування, } \\
\text { прагнення до взаємодії } 3 \text { представниками різних } \\
\text { культур, уміння вироблення стратегії комунікації. }\end{array}$ \\
\hline $\begin{array}{l}\text { Рівень оволодіння іноземною } \\
\text { мовою }\end{array}$ & $\begin{array}{l}\text { Знання та навички фонетики, лексики, граматики. } \\
\text { Сформованість навичок аудіювання, говоріння, } \\
\text { читання, письма. }\end{array}$ \\
\hline $\begin{array}{l}\text { Орієнтація на майбутню } \\
\text { професійну діяльність }\end{array}$ & $\begin{array}{l}\text { Уміння вироблення стратегії і тактики мовної } \\
\text { поведінки, готовність до майбутньої професійної } \\
\text { діяльності, уміння моделювання ситуацій } \\
\text { перенесенням у площину майбутньої професійної } \\
\text { діяльності. Уміння пошуку інформації іноземною } \\
\text { мовою, пов'язаної } 3 \text { майбутньою професійною } \\
\text { діяльністю. }\end{array}$ \\
\hline
\end{tabular}

Висновки i перспективи подальших розвідок. Формування міжкультурної комунікативної компетенції - процес безперервний і циклічний, ймовірно, довжиною у все життя. Це сплав навчання й особистісного міжкультурного досвіду індивіда, оскільки однієї тільки аудиторної роботи недостатньо для формування міжкультурної комунікативної компетентності.

Навчання іноземних мов забезпечить студентам уміння правильно формувати власну комунікативну стратегію та проявляти себе як активного члена міжкультурного комунікативного процесу, що забезпечить ефективність майбутньої професійної діяльності та допоможе адаптуватися у сучасному глобалізованому світі.

Зазначимо, що в процесі досягнення поставленої мети ми прагнули дати узагальнений огляд розглянутої проблематики і показати іï значення в сучасній системі професійної підготовки фахівців технічного та гуманітарного профілю. Тому наступним етапом нашого дослідження постане пошук відповідних форм, методів і засобів формування міжкультурної комунікативної компетентності майбутніх фахівців.

\section{СПИСОК ВИКОРИСТАНИХ ДЖЕРЕЛ}

Загальноєвропейські Рекомендації з мовної освіти: вивчення, викладання, оцінювання (2003). наук. ред. Ніколаєва С. Ю. Київ: Ленвіт, 273 с

Міністерство освіти і науки України (2014). Закон України «Про вищу освіту». URL : https://zakon.rada.gov.ua/laws/show/1556-18. [Дата звернення 21.01.2020].

Про Національну стратегію розвитку освіти в Україні на період до 2021 року (2013) URL: https://zakon.rada.gov.ua/laws/show/344/2013 [Дата звернення 20. 02. 2020]. 
Стратегія комунікації у сфері європейської інтеграції на 2018-2021 роки (2017): схвалено розпорядженням Кабінету Міністрів України від 25 жовтня 2017 р. № 779-p URL: https://zakon.rada.gov.ua/laws/show/779-2017-\%D1\%80 [Дата звернення 20. 02. 2020].

Byram Michael (2004) Assessing Intercultural Competence in Language Teaching. Sprogforum. №18. Vol. 6. P. 8-13.

Brünnemann Karin (2013) The Strategic Importance of Intercultural Competency for Project Managers in the 21st Century. Working Paper Series. University of Applied Sciences of Vienna, No.79

\section{REFERENCES}

Zahalnoievropeiski Rekomendatsii z movnoi osvity: vyvchennia, vykladannia, otsiniuvannia (Common European Framework of Reference for Languages: Learning, Teaching and Assessment) (2003) nauk. red. Nikolaieva S. Yu. Kyiv: Lenvit, 273 s. (in Ukrainian)

Ministry of Education and Science of Ukraine. (2014). Zakon Ukrainy "Pro vyshchu osvit" [The Law of Ukraine «On Higher Education» URL: https://zakon.rada.gov.ua/laws/show/1556-18 [Data zvernennia 21 .01.2020]. (in Ukrainian)

Pro Natsionalnu stratehiiu rozvytku osvity v Ukraini na period do 2021 roku (2013) (On National Strategy of Education Development in Ukraine for the Period to 2021 (2013)) URL: https://zakon.rada.gov.ua/laws/show/344/2013 [Data zvernennia 20. 02. 2020]. (in Ukrainian)

Stratehiia komunikatsii u sferi yevropeiskoi intehratsii na 2018-2021 roky (Communication strategy in the field of European integration for 2018-2021) (2017): skhvaleno rozporiadzhenniam Kabinetu Ministriv Ukrainy vid 25 zhovtnia 2017 r. № 779-r URL: https://zakon.rada.gov.ua/laws/show/779-2017-\%D1\%80 [Data zvernennia 20.02.2020] (in Ukrainian)

Byram Michael (2004) Assessing Intercultural Competence in Language Teaching. Sprogforum. No18. Vol. 6. P. 8-13.

Brünnemann Karin (2013) The Strategic Importance of Intercultural Competency for Project Managers in the 21st Century. Working Paper Series. University of Applied Sciences of Vienna, No.79 


\title{
INTERCULTURAL COMMUNICATIVE COMPETENCE OF FUTURE SPECIALISTS IN TECHNICAL AND HUMANITARIAN SPHERE IN THE CONTEXT OF GLOBALIZATION OF EDUCATIONAL SPACE
}

\author{
Iryna Zabiiaka \\ PhD in Pedagogy, \\ Lecturer at the Department of Ukrainian and Foreign Linguistics , \\ Lutsk National Technical University, \\ Lutsk, Ukraine \\ ORCID : 0000-0002-9535-5490 \\ e-mail: irina.zabiiaka@ukr.net
}

Svitlana Lobanova

$\mathrm{PhD}$ in Pedagogy, Associate Professor Associate Professor at the Department of Foreign Languages of Humanities Specialties, Lesia Ukrainka Eastern European National University,

Lutsk, Ukraine

ORCID: 0000-0002-4432-3552

e-mail: svitlanalobanova000@gmail.com

\begin{abstract}
The article deals with the problems of formation and development of intercultural communicative competence of future specialists in technical and humanitarian sphere in the context of globalization of educational space. Based on the generalization of the basic scientific conceptual and categorical features of the phenomenon that is studied, the intercultural communicative competence of the future specialists of technical and humanitarian sphere is interpreted as an integrative, dynamic, capable of self-development, professional-personal quality, ensuring success in the intercultural development, ensuring success in solving the problems in the intercultural communication, adaptation and self-realization of the specialists of technical and humanitarian sphere in a foreign-language society. The notion «intercultural communicative competence» is considered, its structure and its main components are determined. The essential characteristics of intercultural communicative competence structural components as well as competence as an integrative quality of future specialist were developed. The peculiarities of formation of intercultural communicative competence of future specialists while studying the foreign languages are justified. The pedagogical technologies which provide its effective formation are determined. In this paper the criteria and indicators of the formation of intercultural communicative competence of future specialists of technical and humanitarian sphere in the process of foreign languages studying were considered. The main objective of this paper was to make a general review of this problem and to show its actuality in the modern system of professional education of the specialists in technical and humanitarian sphere.
\end{abstract}

Key words: intercultural communicative competence, intercultural communication, international communication, specialists of technical and humanitarian sphere, professional and communicative competences. 